\title{
KUALITAS LAPORAN KEUANGAN UKM DI KOTA PEKANBARU
}

\author{
Fenny Trisnawati dan Jawanri Citra P. Situmorang \\ Pendidikan Ekonomi FKIP Universitas Riau \\ E-mail: fenny_tr@yahoo.com
}

\begin{abstract}
The development of SMEs in the city of Pekanbaru are very rapidly both in urban and in rural areas. But there are still many SMEs whose management is not maximized both in managerially and financially. This study aims to determine how the quality of the financial statements of SMEs in the city of Pekanbaru. Taken 100 SME units in the city of Pekanbaru as sample. To determine the quality of the financial statements, there are thing that will be examined: (1) the presence or absence of accounting records, (2) there is or is not doingthe recording and accounting reporting, (3) the presence or absence special part of routine accounting, (4) components of the financial statements. The results showed that as many as $84 \%$ of SME businessmen keep records of transactions, but only $61 \%$ were making financial recordingregularly. As many as $10 \%$ of SMEs have a special section which carry the recording and reporting of accounting. Only $1 \%$ of employers that presents the components of the complete financial statements. The majority of SMEs are as much as 32\% present a statement of financial position and income statement in the financial statements. This suggests that the low quality of the financial statements of SMEs in Pekanbaru that reflects a lack of understanding and knowledge of the importance of accounting for business continuity support.
\end{abstract}

\section{Keywords: the quality of financial statement, SAK ETAP, SME, financial report.}

\section{PENDAHULUAN}

Bisnis UKM tersebar merata di seluruh Indonesia dan jumlahnya terus mengalami peningkatan dari tahun ke tahun. Usaha kecil dan menengah ini adalah jenis usaha yang banyak ditekuni oleh sebagian besar masyarakat Indonesia.Jenis bidang usaha UMKM ini beragam, mulai dari perdagangan, jasa dan industri. Menurut data pada Kementrian Koperasi dan Usaha Kecil dan Menengah, pada akhir tahun 2012, jumlah UMKM di Indonesia 56,53 juta unit dengan kontribusi terhadap Produk Domestik Bruto sebesar $59,08 \%$. Jumlah ini mengalami peningkatan dari tahun 2011 sebanyak 1,32 juta unit atau sebesar 2,41\%. Kontribusi UMKM terhadap tenaga kerja juga mengalami peningkatan pada tahun 2012 dibandingkan tahun sebelumnya yaitu5,94 juta orang atau terjadi peningkatan sebesar $5,83 \%$.

Peningkatan jumlah UMKM yang terjadi menunjukkan bahwa ini adalah jenis usaha yang memiliki potensi yang besar untuk berkembang. Jumlah pengangguran yang terus bertambah tiap tahunnya mendorong untuk menciptakan wirausaha baru, dan UMKM adalah sarana untuk menciptakan wirausaha baru. Pertumbuhan UMKM berperan dalam menyerap tenaga kerja dan juga dapat menekan jumlah pengangguran. Hal ini menunjukkan peran UMKM yang cukup besar dalam perkembangan perekonomian Indonesia. Berdasarkan fakta ini, UMKM perlu untuk 
terus dikembangkan dan perlu ditingkatkan pengelolaannya menjadi lebih baik dan profesional.

Pada tahun 2015 akan dibangun Masyarakat Ekonomi Asean (MEA). Pembentukan Komunitas ASEAN 2015 berlandaskan pada 3 pilar, yaitu Komunitas Keamanan ASEAN (ASEAN Security Community), Komunitas Ekonomi ASEAN (ASEAN Economic Community), dan Komunitas Sosial Budaya ASEAN (ASEAN Socio-Cultural Community). Komunitas Ekonomi ASEAN (ASEAN Economic Community/AEC) 2015, akan diarahkan kepada pembentukan sebuah integrasi ekonomi kawasan dengan mengurangi biaya transaksi perdagangan, memperbaiki fasilitas perdagangan dan bisnis, serta meningkatkan daya saing sektor UMKM.

Adanya MEA pada tahun 2015, menjadikan UMKM harus lebih meningkatkan daya saingnya di pasar luar negeri, tidak hanya di pasar dalam negeri saja. Kondisi UMKM di Indonesia saat ini masih ditemui yang berada pada kondisi yang kurang sehat. Kondisi kurang sehat ini diakibatkan karena kurang maksimalnya pengelolaan usaha dari segi manajerial dan finansial. Kebanyakan UMKM yang ditemui tidak memiliki strategi bisnis yang jelas, mereka hanya sekedar menjalankan usaha tanpa disertai langkah-langkah jelas untuk mengembankan dan mencapai peningkatan dalam usaha yang dijalankannya. Kendala lain yang ditemui dalam pengembangan UMKM adalah laporan keuangan yang tidak tertib atau bahkan tidak memiliki laporan keuangan sama sekali. Hal ini terjadi karena rendahnya pendidikan dan tidak adanya pengetahuan mengenai cara menyusun laporan keuangan yang baik dan benar. Masih banyak UMKM yang melakukan perhitungan laba dengan mengurangi pemasukan dengan pengeluaran. Sebagian besar UMKM yang ada memiliki anggapan bahwa menyusun laporan keuangan adalah hal yang mudah dan tidak terlalu penting untuk dilakukan, asalkan mereka memperoleh penghasilan dari usaha yang mereka lakukan.

Anggapan keliru yang dimiliki oleh sebagian besar pengusaha UMKM ini harus diperbaiki. Informasi akuntansi adalah hal yang sangat penting dalam keberlangsungan suatu usaha. Informasi akuntansi, dalam hal ini laporan keuangan adalah sarana komunikasi mengenai kondisi keuangan dan perkembangan suatu usaha. Informasi ini sebagai dasar untuk mengambil keputusan dan menentukan strategi usaha yang akan dilakukan. Pihak perbankan juga menggunakan laporan keuangan sebagai informasi dan dasar pertimbangan bagi mereka untuk memberikan pinjaman. Hal ini dilakukan karena pihak bank perlu mengetahui bagaimana kelayakan dan prospek usaha di masa yang akan datang.

Banyak UMKM yang telah berdiri dengan modal sendiri, pengelolaan tersendiri dan tidak ada rencana pengembangan usaha. Padahal berdasarkan data dari Kementerian koperasi dan UKM pemerintah telah menargetkan dana sekitar 20 triliun untuk pengembangan UMKM yang ada di seluruh Indonesia. program ini diselengarakan dengan kerjasama dengan berbagai pihak perbankan dan juga lembaga-lembaga pembiayaan lainnya yang sengaja ditunjuk oleh pemerintah. Program ini sering disebut dengan KUR (Kredit Usaha Rakyat). Harapannya adalah agar masyarakat semakin mandiri dan memaksimalkan potensi-potensi yang ada didaerah, sehingga akan memunculkan pelaku-pelaku usaha yang baru yang selanjutnya akan dapat menyerap tenaga kerja serta dapat menekan angka kemiskinan yang ada dimasyarakat.

Ikatan Akuntan Indonesia (IAI) telah menerbitkan Standar Akuntansi Keuangan untuk Entitas Tanpa Akuntabilitas Publik (SAK-ETAP). Standar ini berlaku secara efektif untuk penyusun laporan keuangan yang dimulai pada atau setelah 1 Januari 2011. SAK-ETAP dirancang dengan lebih sederhana dan mudah dipahami, standar ini sesuai dengan 
kondisi usaha kecil dan menengah yang ada di Indonesia. Dengan adanya standar ini maka diharapkan laporan keuangan yang dihasilkan akan seragam dan berkualitas.

Pekanbaru sebagai ibukota provinsi Riau merupakan kota yang pesat perkembangannya dan kegiatan perekonomian yang dinamis. Hal ini ditandai dengan bermunculannya berbagai jenis usaha di kota Pekanbaru.Pada tahun 2008, kota Pekanbaru memiliki UMKM sebanyak 67.728 yang bergerak di hampir seluruh bidang usaha. Empat bidang usaha UMKM terbesar adalah yang bergerak di sektor produksi, perdagangan, jasa dan industri.

Perkembangan dan kemajuan UMKM di kota Pekanbaru ini perlu dukungan dari berbagai pihak, terutama pemerintah daerah. Salah satu bentuk dukungan yang diperlukan oleh pengusaha UMKM adalah dari sisi pembiayaan. Banyak UMKM yang sulit berkembang disebabkan karena kurangnya modal untuk mengembangkan usaha. Namun, di sisi lain pihak perbankan sulit untuk memberikan pinjaman karena tidak adanya informasi keuangan yang lengkap dari pengusaha. Informasi keuangan ini akan dijadikan pihak bank sebagai dasar pertimbangan dalam mengucurkan kredit.

UKM yang terus meningkat jumlahnya di kota Pekanbaru sudah selayaknya mendapat perhatian khusus. Peranan UKM dalam menyerap tenaga kerja pun tidak disangsikan lagi. Kesulitan UKM untuk berkembang disebabkan kesulitan dalam permodalan perlu mendapat penyelesaian yang menyeluruh dan tepat sasaran.

Terbatasnya pengetahuan UKM tentang pembukuan dan laporan keuangan perlu medapat perhatian yang serius dari berbagai pihak. Penelitian ini bertujuan untuk mengetahui kondisi UKM di lapangan, khususnya tentang laporan keuangan dan pencatatan keuangan yang telah dilakukan selama ini terhadap usaha tersebut. Secara spesifik penelitian ini bertujuan untuk mengetahui kualitas laporan keuangan UKM yang ada di kota Pekanbaru.

Melalui penelitian ini nantinya diharapkan dapat diperoleh gambaran mengenai kualitas laporan keuangan usaha kecil dan menengah yang ada di kota Pekanbaru. Hasil dari penelitian ini nantinya akan memberikan informasi kepada pihak terkait, dalam hal ini Dinas Koperasi dan Usaha Kecil Menengah mengenai kondisi riilkualitas laporan keuangan UKM di kota Pekanbaru. Informasi yang diperoleh ini nantinya diharapkan akan dapat dijadikan sebagai dasar pengambilan kebijakan untuk mengembangkan UKM ke arah yang lebih baik di masa yang akan datang.

\section{HASIL DAN PEMBAHASAN Pengertian UKM}

Dalam Undang-undang No. 20 Tahun 2008 disebutkan bahwa pengertian Usaha Mikro, Kecil dan Menengah adalah sebagai berikut:

a. Usaha mikro adalah usaha produktif milik orang perorangan dan/atau badan usaha perorangan yang memenuhi kriteria Usaha Mikro, yaitu memiliki aset maksimum Rp50 juta dengan omzet maksimum Rp300 juta.

b. Usaha kecil adalah usaha ekonomi produktif yang berdiri sendiri, yang dilakukan oleh orang perorangan atau badan usaha yang bukan merupakan anak perusahaan atau bukan cabang perusahaan yang dimiliki, dikuasai, atau menjadi bagian baik langsung maupun tidak langsung dari usaha menengah atau usaha besar yang memenuhi kriteria usaha kecil, yaitu memiliki aset lebih dari Rp50 juta sampai dengan Rp500 juta dengan omzet berkisar lebih dari Rp300 juta sampai dengan Rp2,5 miliar.

c. Usaha menengah adalah usaha ekonomi produktif yang berdiri sendiri, yang dilakukan oleh orang perseorangan atau badan usaha yang bukan merupakan anak perusahaan atau cabang perusahaan yang dimiliki. 
Dikuasai, atau menjadi bagian baik langsung maupun tidak langsung dengan usaha kecil atau usaha besar dengan jumlah kekayaan bersih atau hasil penjualan tahunan sebagaimana diatur dalam undang-undang ini, yaitu memiliki aset lebih dari Rp500 juta sampai dengan Rp10 miliar dengan omzet Rp2,5 miliar sampai dengan Rp50 miliar.

Bank Indonesia mendefenisikan kriteria usaha kecil adalah sebagai berikut:

1. Modalnya kurang dari Rp20 juta

2. Untuk satu putaran usahanya hanya membutuhkan dana Rp 5 juta

3. Memiliki kekayaan maksimum Rp600 juta diluar tanah dan bangunan

4. Omset tahunan paling banyak $\mathrm{Rp} 1$ miliar

Tabel 1. Kriteria Jenis Usaha Berdasarkan Jumlah Tenaga Kerja

\begin{tabular}{|l|c|}
\hline \multicolumn{1}{|c|}{ Jenis Usaha } & $\begin{array}{c}\text { Jumlah Tenaga } \\
\text { Kerja }\end{array}$ \\
\hline Usaha Kecil & $1-19$ orang \\
\hline $\begin{array}{l}\text { Usaha } \\
\text { Menengah }\end{array}$ & $20-99$ orang \\
\hline Usaha Besar & $>99$ orang \\
\hline
\end{tabular}

Sumber : Badan Pusat Statistik (2011)

Defenisi usaha kecil dan menengah sangat beragam. Guna mencapai tujuan penelitian ini, maka defenisi usaha kecil dan menengah yang digunakan mengacu pada pengelompokan usaha berdasarkan skala usaha yang ditetapkan oleh Badan Pusat Statistik (BPS). BPS mengklasifikasikan dan membagi usaha ke dalam tiga skala yaitu usaha kecil, usaha menengah dan usaha besar. Pembagian ini berdasarkan jumlah karyawan yang dimiliki oleh suatu usaha. Pada Tabel 1 disajikan pembagian jenis usaha menurut BPS.

Urata (2000) yang telah mengamati perkembangan usaha kecil di Indonesia, menegaskan bahwa usaha kecil di Indonesia memainkan peranan penting dalam beberapa hal, antara lain:

1. Usaha kecil merupakan pemain utama kegiatan ekonomi Indonesia.
2. Penyedia kesempatan kerja.

3. Pemain penting dalam pengembangan ekonomi lokal dan pengembangan masyarakat.

4. Pencipta pasar dan inovasi melalui fleksibilitas dan sensitivitasnya yang dinamis serta keterikatannya dengan beberapa perusahaan.

5. Memberikan kontribusi terhadap peningkatan ekspor non migas.

\section{Informasi Akuntansi}

Akuntansi berperan sebagai penyedia informasi berupa laporan keuangan kepada pemangku kepentingan (stakeholders). Informasi ini berupa aktivitas, kinerja dan kondisi keuangan perusahaan yang akan digunakan untuk pengambilan keputusan.

Menurut Rudianto (2009), walaupun setiap perusahaan memiliki bidang usaha dan karakteristik yang berbeda satu sama lain sehingga rincian laporan keuangan satu perusahaan dengan perusahaan lainnya dapat berbeda, tetapi setiap laporan keuangan yang dihasilkan oleh setiap institusi harus memenuhi standar kualitas berikut ini :

1. Relevan, artinya, laporan keuangan harus sesuai dengan tujuan operasional perusahaan dan memenuhi kebutuhan pemakai dalam proses pengambilan keputusan.

2. Dapat dipahami, artinya laporan keuangan mudah untuk dipahami oleh pihak pemakai laporan keuangan.

3. Keandalan (reliable), artinya informasi laporan keuangan harus bebas dari pengertian yang menyesatkan, kesalahan material, dan dapat diandalkan pemakainya sebagai penyajian yang tulus dan jujur (faithful representation).

4. Netralitas, artinya informasi akuntansi harus diarahkan pada kebutuhan umum pemakai, tidak bergantung pada kebutuhan dan keinginan pihak tertentu.

5. Tepatwaktu, laporan keuangan harus dapat disajikan sedini mungkin agar 
dapat digunakansebagai dasar pengambilan keputusan perusahaan. Laporan keuangan perusahaan yang terlambat pelaporannya akan membuat keputusan perusahaan menjadi tertunda.

6. Kelengkapan, artinya informasi dalam laporan keuangan harus lengkap dalam batasan materialitas dan biaya.

7. Dapat dibandingkan, artinya informasi akuntansi harus dapat dibandingkan dengan laporan periode sebelumnya serta dapat dibandingkan dengan perusahaan lain yang sejenis.

\section{Laporan Keuangan pada UKM}

Menurut Kieso (2007), laporan keuangan merupakan sarana pengkomunikasian informasi keuangan utama kepada pihak-pihak di luar perusahaan. Laporan keuangan adalah suatu penyajian terstruktur dari posisi keuangan, kinerja keuangan dan arus kas suatu entitas. Laporan keuangan akan menyajikan kondisi keuangan yang ada pada suatu usaha atau perusahaan. Oleh karena itu, setiap entitas sangat diharapkan untuk menyajikan laporan keuangannya untuk mengetahui kondisi perusahaan tersebut, sehingga pihak manajerial dapat mengambil keputusan untuk pengembangan ataupun untuk mempertahankan usaha tersebut.

Laporan keuangan merupakan hasil akhir dari serangkaian kegiatan akuntansi dari suatu perusahaan. Laporan keuangan ini nantinya akan dimanfaatkan oleh banyak pihak, baik pihak eksternal perusahaan maupun pihak internal perusahaan sendiri. Mengingat banyaknya pihak-pihak yang berkepentingan terhadap laporan keuangan perusahaan, maka dalam menyusun laporan keuangan hendaknya sesuai dengan standar yang berlaku, sehingga dapat memenuhi kebutuhan semua pihak.

Pada umumnya praktik kegiatan UKM berjalan tanpa mengandalka informasi keuangan yang disusun secara tertib dan teratur. Banyak UKM dapat berjalan normal tanpa dukungan informasi keuangan yang memadai. Mereka dapat berhasil tanpa laporan keuangan yang dijadikan dasar dalam pengambilan keputusan. Pengambilan keputusan hanya didasarkan pada intuisi dan kebiasaan yang berasal dari pengalaman sebelumnya.

Dalam sejumlah penelitian yang dilakukan tentang faktor yang mempengaruhi penggunaan informasi akuntansi ditemukan bahwa variabel signifikan yang berpengaruh antara lain masa memimpin perusahaan, pendidikan pemilik, umur perusahaan dan pelatihan akuntansi yang diikuti pemilik (Handayani, 2011). Selain itu, dalam sebuah penelitiannya, Wahyudi (2009) mengungkapkan bahwa faktor-faktor yang mempengaruhi penyiapan dan penggunaan informasi akuntansi pada perusahaan kecil dan menengah adalah:

1. Pendidikan pemilik atau manajer

2. Skala usaha

3. Masa memimpin perusahaan

4. Umur perusahaan

5. Pelatihan akuntansi yang diikuti pemilik atau manajer

Selain itu menurut Golrida dalam

Dita Purnama Sari (2013), beberapa manfaat pembukuan bagi usaha kecil antara lain:

1. Mempermudah pelaksanaan usaha

Pembukuan merupakan bagian dari administrasi usaha. Salah satu tujuan administrasi adalah mempermudah pelaksanaan usaha. Bagi usaha kecil administrasi keuangan merupakan administrasi yang paling penting dibandingkan yang lainnya karena jumlah orang terlibat masih sedikit. Dapat dibayangkan pengusaha yang tidak melaksanakan pembukuan atau pencatatan akuntansi, usahanya akan menemukan kesulitan dalam pelaksanaan usahanya.

2. Evaluasi kinerja

Salah satu manfaat pembukuan adalah untuk alat evaluasi kinerja usaha. Dari pembukuan usaha yang tertata dengan baik, kondisi ekonomi perusahaan 
lebih mudah dilihat dan dianalisis. Hal ini akan mempermudah perusahaan mengevaluasi kinerjanya guna melakukan perbaikan-perbaikan di masa yang akan datang.

3. Perencanaan yang lebih efektif Pembukuan yang tertata baik dan rutin akan memudahkan perusahaan melakukan perencanaan-perencanaan usaha ke depan. Selanjutnya, dengan mengetahui volume usaha pada kurun waktu tertentu, perusahaan akan dapat menganalisis kemampuan dan kelemahannya untuk pengembangan usaha di masa yang akan datang.

4. Pemeriksaan pihak luar

Usaha yang semakin besar menyebabkan perusahaan tidak dapat terhindar dari lingkungan luar misalnya, perpejakan. Perhitungan pajak didasarkan pada pembukuan perusahaan. Oleh karena itu, perusahaan harus melaksanakan pembukuan perusahaan yang baik sehingga ketika usahanya dipertanggungjawabkan kepada pihak luar, dapat dilakukan dengan baik.

\section{SAK-ETAP}

IAI telah menerbitkan Standar Akuntansi Keuangan Entitas Tanpa Akuntabilitas Publik (SAK-ETAP) yang berlaku efektif untuk penyusunan laporan keuangan yang dimulai pada atau setelah 1 Januari 2011. SAK yang berbasis IFRS ditujukan bagi entitas yang mempunyai tanggung jawab publlik signifikan dan entitas yang banyak melakukan kegiatan lintas negara. SAK umum tersebut rumit untuk dipahami serta diterapkan bagi sebagian besar entitas usaha di Indonesia yang berskala kecil dan menengah.

Sesuai dengan ruang lingkup SAK ETAP maka Standar ini dimaksudkan untuk digunakan oleh entitas tanpa akuntabilitas publik. Entitas tanpa akuntabilitas publik yang dimaksud adalah entitas yang tidak memiliki akuntabilitas publik signifikan; dan tidak menerbitkan laporan keuangan untuk tujuan umum (general purpose financial statement) bagi pengguna eksternal. Contoh pengguna eksternal adalah pemilik yang tidak terlibat langsung dalam pengelolaan usaha, kreditur, dan lembaga pemeringkat kredit. Ruang lingkup standar ini juga menjelaskan bahwa Entitas dikatakan memiliki akuntabilitas publik signifikan jika proses pengajuan pernyataan pendaftaran pada otoritas pasar modal atau regulator lain untuk tujuan penerbitan efek di pasar modal atau entitas menguasai aset dalam kapasitas sebagai fidusia untuk sekelompok besar masyarakat, seperti bank, entitas asuransi, pialang dan atau pedagang efek, dana pensiun, reksa dana dan bank investasi.

Munculnya SAK-ETAP dilatar belakangi oleh:

1. Adanya kebutuhan standar akuntansi keuangan untuk usaha kecil dan menengah. Dalam hal ini akibat sulit untuk mendapatkan pinjaman melalui pihak perbankan dan sebagian besar perusahaan yang ada di Indonesia merupakan kelompok usaha mikro, kecil dan menengah.

2. Program konvergensi IFRS

a. IFRS untuk perusahaan yang mempunyai akuntabilitas publik dan aktivitas lintas negara, bersifat kompleks, fair value dan sering berubah.

b. SAK ETAP dikeluarkan sebelum SAK umum (berbasis IFRS) berlaku efektif 1 Januari 2011.

c. Perusahaan yang memenuhi syarat untuk menggunakan SAK ETAP dapat memilih menggunakan SAK ETAP atau SAK umum.

Menurut Ikatan Akuntan Indonesia dalam SAK ETAP (2011), laporan keuangan adalah bagian dari proses pelaporan keuangan, dan laporan keuangan yang lengkap meliputi :

1. Neraca

Neraca merupakan bagian dari laporan keuangan suatu perusahaan yang dihasilkan pada suatu periode 
akuntansi yang menunjukkan posisi keuangan perusahaan pada akhir periode tersebut. Neraca minimal mencakup pos-pos sebagai berikut : kas dan setara kas; piutang usaha dan piutang lainnya; persediaan; properti investasi;asset tetap; asset tidak berwujud; utang usaha dan utang lainnya; asset dan kewajiban pajak; kewjiban diestimasi dan ekuitas.

2. Laporan laba rugi

Laporan laba-rugi menyajikan hubungan antara penghasilan dan beban dari entitas. Laba sering digunakan sebagai ukuran kinerja atau sebagai dasar untuk pengukuran lain, seperti tingkat pengembalian investasi atau laba per saham. Unsur-unsur laporan keuangan secara langsung terkait dengan pengukuran laba adalah penghasilan dan beban. Laporan labarugi minimal mencakup pos-pos sebagai berikut: pendapatan; beban keuangan; bagian laba atau rugi dari investasi yang menggunakan metode ekuitas; beban pajak ; laba atau rugi neto.

3. Laporan perubahan ekuitas

Dalam laporan ini menunjukkan :

a. Seluruh perubahan dalam ekuitas untuk satu periode, termasuk didalamnya pos pendapatan dan beban yang diakui secara langsung dalam ekuitas untuk periode tersebut. Pengaruh perubahan kebijakan akuntansi dan koreksi kesalahan yang diakui dalam periode tersebut atau

b. Perubahan ekuitas selain perubahan yang timbul dari transaksi dengan pemilik dalam kapasitasnya sebagai pemilik termasuk jumlah investasi, penghitungandevidendandistribusi lain

kepemilikekuitasselamasuatuperio de.

4. Laporan arus kas

Laporan arus kas menyajikan laporan informasi perubahan historis atas kas dan setara kas entitas, yang menunjukkan secara terpisah perubahan yang terjadi selama satu periode dari aktivitas operasi, nvestasi dan pendanaan.

5. Catatan atas laporan keuangan

Catatan atas laporan keuangan berisi ringkasan kebijakan akuntansi yang signifikan dan informasi penjelasan lainnya serta tambahan informasi yang disajikan dalam laporan keuangan. Catatan atas laporan keuangan memberikan penjelasan naratif atau rincian jumlah yang disajikan dalam laporan keuangan dan informasi pospos yang tidak memenuhi kriteria pengakuan dalam laporan keuangan.

Manfaat diterbitkannya SAK ETAP antara lain:

1. Diharapkan dengan adanya SAK ETAP, perusahaan kecil, menengah mampu untuk:

a. Menyusun laporan keuangannya sendiri.

b. Dapat diaudit dan mendapatkan opini audit, sehingga dapat menggunakan laporan keuangannya untuk mendapatkan dana (misalnya dari bank) untuk pengembangan usaha.

2. Lebih sederhana dibandingkan dengan PSAK IFRS sehingga lebih mudah dalam implementasinya.

3. Tetap memberikan informasi yang handal dalam penyajian laporan keuangan.

SAK ETAP merupakan standar akuntansi yang dikeluarkan oleh IAI melalui Dewan Stadar Akuntansi Indonesia untuk entitas tanpa akuntabilitas publik yang termasuk di dalamnya UMKM dan koperasi. Dengan adanya SAK ETAP ini, laporan keuangan setiap usaha kecil dan menengah dapat menjadi lebih berkualitas, transparan dan akuntabel.

Penelitian ini bersifat deskriptif dengan menerapkan pendekatan survey. Lokasi penelitian dilakukan di kota Pekanbaru. Teknik pengumpulan data dilakukan denganmendistribusikan 
kuisioner secara langsung dan sekaligus dilakukan wawancara dengan responden yang merupakan pengusaha UKM.

Berdasarkan data yang diperoleh dari Dinas Koperasi dan UMKM Kota Pekanbaru periode 31 Desember 2011, jumlah usaha kecil yang ada di Pekanbaru adalah 1937 unit dan usaha menengah 694 unit. Penelitian ini menerapkan sampel berdasarkan kriteria sebagai berikut:

a. Dikelola oleh pemiliknya sendiri.

b. Memiliki sedikitnya 2 atau lebih karyawan (termasuk pemilik).

c. Memiliki umur usaha minimal 2 tahun.

Cara penarikan sampel menggunakan simple random sampling dan ditetapkan sebanyak 100 unit usaha UKM sebagai sampel dalam penelitian ini.

Sumber data pada penelitian menggunakan data primer dan data sekunder. Data primer diperoleh dari hasil wawancara dan data sekunder diperoleh dari Departemen Koperasi dan UMKM kota Pekanbaru.

Data yang akan digunakan dalam penelitian ini adalah latar belakang pendidikan, pendidikan terakhir dan kualitas laporan keuangan. Kualitas laporan keuangan yang dimaksud adalah terdapat minimal tiga komponen laporan keuangan, yaitu, laporan posisi keuangan (neraca), laporan perubahan modal dan lapora laba rugi.

Data yang diperoleh selanjutnya akan dianalisis dengan analisis deskriptif. Dari hasil analisis data akan diperoleh bagaimana kondisi laporan keuangan UKM yang sebenarnya di kota Pekanbaru sebagai berikut.

\section{Karakteristik Responden}

Pelaku UKM di kota Pekanbaru terdiri dari berbagai jenjang usia dengan berbagai latar belakang usaha yang berbeda-beda. Umur responden merupakan karakteristik pokok yang berpengaruh dalam tatanan kehidupan sosial ekonomi seseorang termasuk dalam usaha bisnis.
Tabel 2 menyajikan struktur umur pelaku UKM yang menjadi responden.

Tabel 2. Umur Responden

\begin{tabular}{|c|c|c|}
\hline $\begin{array}{c}\text { Kelompok } \\
\text { Umur } \\
\text { (Thn.) }\end{array}$ & $\begin{array}{c}\text { Frekuensi } \\
\text { (orang) }\end{array}$ & $(\boldsymbol{\%})$ \\
\hline $20-25$ & 4 & 4 \\
\hline $26-30$ & 23 & 23 \\
\hline $31-35$ & 14 & 14 \\
\hline $36-40$ & 26 & 26 \\
\hline $41-45$ & 12 & 12 \\
\hline$>45$ & 21 & 21 \\
\hline Jumlah & 100 & 100 \\
\hline
\end{tabular}

\section{Sumber: Data Olahan (2014)}

Dari tabel 2 terlhat bahwa kelompok usia yang dominan adalah kelompok usia $36-$ 40 dan yang paling sedikit adalah kelompok usia $20-25$.

Dilihat dari jenis kelamin pengusahan UKM, maka sebarannya dapat dilihat pada tabel 3 .

\section{Tabel 3. Jenis Kelamin Responden}

\begin{tabular}{|l|c|c|}
\hline $\begin{array}{c}\text { Jenis } \\
\text { Kelamin }\end{array}$ & $\begin{array}{c}\text { Frekuensi } \\
\text { (orang) }\end{array}$ & $\mathbf{( \% )}$ \\
\hline Laki-laki & 68 & 68 \\
\hline Perempuan & 32 & 32 \\
\hline Jumlah & 100 & 100 \\
\hline
\end{tabular}

\section{Sumber: Data Olahan (2014)}

Pada tabel 3 terlihat bahwa jumlah pengusaha UKM dengan jenis kelamin laki-laki lebih banyak daripada jenis kelamin perempuan, yaitu sebesar $68 \%$.

Karakteristik responden berdasarkan tingkat pendidikannya disajikan pada tabel 4 berikut ini.

Tabel 4. Tingkat Pendidikan Responden

\begin{tabular}{|c|c|c|}
\hline $\begin{array}{c}\text { Tingkat } \\
\text { Pendidikan }\end{array}$ & $\begin{array}{c}\text { Frek. } \\
\text { (orang) }\end{array}$ & $(\boldsymbol{\%})$ \\
\hline SMA sederajat & 52 & 52 \\
\hline
\end{tabular}




\begin{tabular}{|l|c|c|}
\hline S1 & 45 & 45 \\
\hline S2 & 1 & 1 \\
\hline Lainnya & 2 & 2 \\
\hline Jumlah & 100 & 100 \\
\hline
\end{tabular}

Sumber: data Olahan (2014)

Dari tabel 4 terlihat bahwa tingkat pendidikan SMA sederajat lebih dominan menjadi pengusaha UKM, yaitu sebanyak $52 \%$ dibandingkan dengan tingkat pendidikan sarjana sebanyak $45 \%$ dan pendidikan strata 2 dengan $1 \%$ dan tingkat pendidikan lainnya yang hanyasebanyak $2 \%$.

Karakteristik responden berdasarkan latar belakang pendidikan dapat dilihat pada tabel 5 .

Tabel 5. Latar Belakang Pendidikan Responden

\begin{tabular}{|l|c|c|}
\hline $\begin{array}{c}\text { Latar } \\
\text { Belakang } \\
\text { Pendidikan }\end{array}$ & $\begin{array}{c}\text { Frek. } \\
\text { (orang) }\end{array}$ & $\boldsymbol{\%}$ \\
\hline Akuntansi & 1 & 1 \\
\hline Manajemen & 19 & 19 \\
\hline Ekonomi & 9 & 9 \\
\hline Lainnya & 71 & 71 \\
\hline Jumlah & 100 & 100 \\
\hline
\end{tabular}

Sumber: Data Olahan (2014)

\section{Karakteristik Usaha}

Karakteristik usaha yang paling menonjol adalah umur usaha. Umur usaha menunjukkan berapa lama usaha tersebut telah berjalan dan juga menunjukkan kemampuan suatu usaha untuk bertahan dalam menjalankan dan mengembangkan suatu bisnis. Pada tabel 6 disajikan umur UKM pada penelitian ini.

UKM dengan usia $2-5$ tahun memiliki porsi terbesar, yaitu sebanyak $54 \%$, yang artinya masih tergolong dalam usaha yang baru dirintis. Namun, tidak sedikit juga UKM yang telah cukup lama dalam menggeluti usahanya, terdapat sebanyak $12 \%$ UKM yang telah berusia lebih dari 10 tahun,

\section{Tabel 6. Umur UKM}

\begin{tabular}{|l|c|c|}
\hline $\begin{array}{c}\text { Umur } \\
\text { Usaha } \\
\text { (Thn.) }\end{array}$ & $\begin{array}{c}\text { Frekuensi } \\
\text { (unit) }\end{array}$ & $\begin{array}{c}\text { Persentase } \\
(\mathbf{\%})\end{array}$ \\
\hline $2-5$ & 54 & 54 \\
\hline $6-10$ & 20 & 20 \\
\hline $10-15$ & 12 & 12 \\
\hline$>15$ & 4 & 4 \\
\hline Jumlah & 100 & 100 \\
\hline
\end{tabular}

Sumber: Data Olahan (2014)

Berbagai macam bidang usaha digeluti oleh pengusaha UKM, mulai dari perdagangan, jasa dan lain-lain. Pada tabel 7 disajikan berbagai bidang usaha UKM. Pada tabel 7 terlihat bahwa bidang usaha yang dominan adalah bidang usaha perdagangan yaitu sebanyak $38 \%$ dan disusun dengan bidang usaha jasa sebanyak $36 \%$.

\section{Tabel 7. Bidang Usaha UKM}

\begin{tabular}{|l|c|c|}
\hline $\begin{array}{c}\text { Bidang } \\
\text { Usaha }\end{array}$ & $\begin{array}{c}\text { Frek. } \\
\text { (Unit) }\end{array}$ & $(\mathbf{\% )}$ \\
\hline Perdagangan & 38 & 38 \\
\hline Manufaktur & 17 & 17 \\
\hline Jasa & 36 & 36 \\
\hline Agrobisnis & 8 & 8 \\
\hline Lainnya & 1 & 1 \\
\hline \multicolumn{1}{|c|}{ Jumlah } & 100 & 100 \\
\hline
\end{tabular}

\section{Sumber: Data Olahan (2014)}

Dilihat dari sisi aset usaha yang diartikan sebagai harta yang dimiliki perusahaan selama menjalankan aktivitas usaha, yang terdiri dari tempat usaha, peralatan yang digunakan, perlengkapan dan lain sebagainya, dapat dilihat pada tabel 8 yang menyajikan total aset rata-rata yang dimiliki oleh UKM.

Tabel 8. Total Aset Rata-rata UKM

\begin{tabular}{|c|c|c|}
\hline $\begin{array}{c}\text { Jumlah Aset } \\
\text { (Rp) }\end{array}$ & $\begin{array}{c}\text { Frek. } \\
\text { (Unit) }\end{array}$ & $\%$ \\
\hline$<100$ Juta & 55 & 55 \\
\hline
\end{tabular}




\begin{tabular}{|c|c|c|}
\hline $100-449$ juta & 32 & 32 \\
\hline 500 juta $-2,5 \mathrm{M}$ & 9 & 9 \\
\hline$>2,5 \mathrm{M}$ & 4 & 4 \\
\hline Jumlah & 100 & 100 \\
\hline
\end{tabular}

\section{Sumber: Data Olahan (2014)}

Tabel 8 menunjukkan bahwa UKM yang memiliki aset kurang dari 100 juta sebanyak $55 \%$ sedangkan UKM yang asetnya lebih besar dari 2,5 $\mathrm{M}$ hanya sebanyak $4 \%$, artinya UKM dengan aset dibawah 100 juta lebih dominan.

Karakteristik usaha dilihat dari modal usaha, maka modal usaha dapat dibedakan atas dua, yaitu, modal sendiri dan modal asing. Modal sendiri adalah yang berasal dari dalam kekayaan perusahaan itu sendiri, misalnya setoran dari pemilik perusahaan. Sedangkan modal asing adalah modal yang bersumber dari luar perusahaan, misalnya pinjaman dari luar perusahaan seperti bank. Tabel 9 menyajikan bagaimana kondisi modal UKM di Pekanbaru.

Tabel 9. Struktur Modal UKM

\begin{tabular}{|c|c|c|}
\hline $\begin{array}{c}\text { Komposisi Modal } \\
\text { Sendiri }\end{array}$ & $\begin{array}{c}\text { Frek. } \\
\text { (Unit) }\end{array}$ & $\%$ \\
\hline $100 \%$ Modal Sendiri & 49 & 49 \\
\hline $\begin{array}{l}75-99 \% \text { Modal } \\
\text { sendiri }\end{array}$ & 31 & 31 \\
\hline $\begin{array}{l}50-74 \% \text { Modal } \\
\text { Sendiri }\end{array}$ & 11 & 11 \\
\hline <50\% modal sendiri & 9 & 9 \\
\hline \multicolumn{1}{|c|}{ Jumlah } & 100 & 100 \\
\hline
\end{tabular}

Sumber: Data Olahan (2014)

Sebanyak $49 \%$ pengusaha UKM menyatakan bahwa modal usahanya berasal dari modal sendiri sedangkan sebanyak $51 \%$ pengusaha UKM menyatakan bahwa modal usahanya selain dari modal sendiri juga berasal dari pinjaman perbankan atau dari pihak lain.

Tenaga kerja yang bekerja pada UKM ini biasanya dikoordinir langsung oleh pengusaha itu sendiri, ada juga pengusaha yang merekrut tenaga kerjanya dari orang-orang terdekatnya, seperti keluarga dan tetangganya. Bahkan ada juga pengusaha yang mengaku sengaja mendatangkan tenaga kerjanya dari kampung halamannya sendiri, dengan alasan para tenaga kerja tersebut dapat lebih dipercaya. Tabel 10 menyajikan jumlah tenaga kerja yang ada pada UKM. Pada tabel 10 terlihat bahwa sebanyak $42 \%$ UKM memperkerjakan $4-5$ orang tenaga kerja.

Tabel 10. Jumlah Tenaga Kerja pada UKM

\begin{tabular}{|l|c|c|}
\hline $\begin{array}{c}\text { Tenaga } \\
\text { Kerja } \\
\text { (orang) }\end{array}$ & $\begin{array}{c}\text { Frek. } \\
\text { (Unit) }\end{array}$ & $\%$ \\
\hline $2-3$ & 40 & 40 \\
\hline $4-5$ & 42 & 42 \\
\hline $6-7$ & 5 & 5 \\
\hline$\geq 8$ & 13 & 13 \\
\hline Jumlah & 100 & 100 \\
\hline
\end{tabular}

\section{Sumber: Data Olahan (2014)}

Karakteristik usaha yang juga harus diperhatikan adalah omset usaha, yaitu besaran penjualan produk barang atau jasa perusahaan dalam waktu tertentu. Omset penjualan ini dihitung berdasarkan penjualan rata-rata UKM dalam satu tahun. Dalam penelitian ini, besaran omset UKM paling dominan adalah kisaran 100 - 449 juta, yaitu sebanyak 49\%. Untuk lebih jelasnya dapat dilihat pada tabel 11 yang menyajikan omset usaha UKM di Pekanbaru.

Tabel 11. Besaran Omset UKM per Tahun

\begin{tabular}{|l|c|c|}
\hline $\begin{array}{c}\text { Omset Usaha } \\
\text { (Rp) }\end{array}$ & $\begin{array}{c}\text { Frek. } \\
\text { (Unit) }\end{array}$ & $\%$ \\
\hline$<100$ juta & 31 & 31 \\
\hline $100-449$ juta & 49 & 49 \\
\hline $500-2,5 \mathrm{M}$ & 17 & 17 \\
\hline$>2,5 \mathrm{M}$ & 3 & 3 \\
\hline Jumlah & 100 & 100 \\
\hline
\end{tabular}

Sumber: Data Olahan (2014) 


\section{Kualitas Laporan Keuangan UKM di Pekanbaru}

Laporan keuangan akan menyajikan kondisi keuangan yang ada pada suatu entitas atau perusahaan. Oleh karena itu, setiap entitas sangat diharapkan dapat menyajikan laporan keuangannya untuk mengetahui kondisi perusahaan tersebut sehat atau tidak. Berdasarkan hal itu pihak manajerial dapat mengambil keputusan untuk pengembangan ataupun untuk mempertahankan usaha tersebut.

Komponen laporan keuangan meliputi pencatatan akuntansi harian secara rutin dan selanjutnya membuat laporan keuangan yang terdiri dari laporan laba rugi, laporan perubahan modal, laporan posisi keuangan (neraca), laporan arus kas perusahaan dan catatan atas laporan keuangan (CALK).

Guna menilai kualitas laporan keuangan yang dibuat pengusaha UKM, hal yang menjadi perhatian adalah :

1. Melakukan pencatatan atas transaksi usaha atau tidak.

2. Ada atau tidaknya divisi atau pegawai khusus terkait dengan pembukuan dan pelaporan keuangan.

3. Rutin atau tidaknya dilakukan pencatatan dan pelaporan keuangan.

4. Komponen laporan keuangan apa saja yang disajikan.

Tabel 12 menyajikan bagaimana kualitas laporan keuangan UKM yang ada di Pekanbaru.

\section{Tabel 12. Kualitas Laporan Keuangan UKM}

\begin{tabular}{|l|c|c|c|}
\hline \multicolumn{1}{|c|}{ Keterangan } & $\begin{array}{c}\text { Ya } \\
(\%)\end{array}$ & $\begin{array}{c}\text { Tidak } \\
(\%)\end{array}$ & $\begin{array}{c}\text { Jml } \\
(\%)\end{array}$ \\
\hline $\begin{array}{l}\text { Melakukan } \\
\text { pencatatan } \\
\text { transaksi } \\
\text { keuangan } \\
\text { usaha }\end{array}$ & 84 & 16 & 100 \\
\hline $\begin{array}{l}\text { Memiliki } \\
\text { pegawai/bagian } \\
\text { khusus yang }\end{array}$ & 10 & 90 & 100 \\
\hline
\end{tabular}

\begin{tabular}{|l|c|c|c|}
\hline $\begin{array}{l}\text { melakukan } \\
\text { pencatatan } \\
\text { akuntansi }\end{array}$ & & & \\
\hline $\begin{array}{l}\text { Melakukan } \\
\text { pencatatan } \\
\text { transaksi } \\
\text { secara rutin }\end{array}$ & 61 & 23 & 84 \\
\hline $\begin{array}{l}\text { Mengetahui } \\
\text { standar } \\
\text { akuntansi } \\
\text { keuangan }\end{array}$ & 10 & 90 & 100 \\
\hline
\end{tabular}

\section{Sumber: Data Olahan (2014)}

\section{a. Pencatatan atas Transaksi Usaha}

Pembukuan atau pencatatan transaksi keuangan perusahaan merupakan proses penting dalam membuat laporan keuangan suatu usaha. Pencatatan transaksi usaha adalah mencatat setiap transaksi yang berhubungan dengan kegiatan usaha. Misalnya transaksi yang berhubugan dengan kas, pembelian (tunai maupun kredit), penjualan, piutang dan utang.

Berdasarkan data pada tabel 12, sebanyak $61 \%$ pengusaha UKM melakukan pencatatan transaksi usahanya secara rutin dan sebanyak $23 \%$ pengusaha UKM mencatat transaksi usahanya tidak rutin. Namun demikian, masih ditemukan pengusaha UKM yang sama sekali tidak melakukan pencatatan transaksi atas usahanya, yaitu sebanyak 16\%. Pengusaha UKM yang tidak melakukan pencatatan sama sekali atas transaksi usahanya tersebut menyatakan bahwa belum membutuhkan pencatatan akuntansi dan pencatatan tidak begitu penting terhadap usaha yang dijalankannya. Hal ini sejalan dengan penelitian Dita Purnama Sari (2013) yang menyatakan bahwa persepsi pengusaha berpengaruh terhadap penyediaan laporan keuangan pada UKM. Pengusaha yang mempunyai persepsi bahwa pencatatan akuntansi tidak penting cenderung untuk tidak melakukan pencatatan transaksi dan tentunya tidak memiliki laporan keuangan.

Pengusaha UKM yang tidak melaksanakan pencatatan akuntansi atas transaksi usahanya mengaku hanya 
mengandalkan daya ingatnya sendiri mengenai transaksi bisnis yang telah dilakukannya. Selain itu, pengusaha UKM tersebut menjalankan aktivitas usahanya tanpa mengetahui persis berapa total kas dan laba usaha yang diperoleh dalam suatu periode tertentu.

Umumnya kendala yang ditemui pengusaha UKM dalam melakukan pencatatan akuntansi adalah sebagai berikut:

1. Pengusaha UKM masih sulit membedakan antara transaksi keuangan pribadi dan transaksi keuangan usahanya. Oleh sebab itu, pengusaha UKM harus mampu untuk konsisten dan disiplin dalam membedakan mana yang pengeluaran untuk pribadi dan mana pengeluaran yang untuk usaha.

2. Pengusaha UKM kurang rajin melakukan pencatatan transaksi keuangan harian, termasuk dokumentasi bukti-bukti transaksi. Hal ini mengakibatkan pengusaha sulit untuk menyajikan laporan keuangan usahanya secara detail dan akuntabel.

3. Kesibukan usaha yang membuat pembukuan transaki menjadi terlupakan, hal ini terutama terjadi pada pengusaha yang tidak memiliki pegawai/bagian khusus pencatatan keuangan. Apabila sudah sore, pengusaha mengaku sudah enggan untuk melakukan pencatatan transaksi, disebabkan faktor kelelahan

4. Latar belakang pendidikan pengusaha UKM yang bukan dari bidang akuntansi, manajemen, ekonomi atau tata buku, menjadikan pemahamannya tentang akuntansi terbatas.

\section{b. Ada Pegawai/bagian Khusus Akuntansi}

Tidak adanya staf atau pegawai yang paham akan akuntansi, hal ini juga membuat UKM sulit untuk menyajikan laporan keuangan. Dalam penelitian ini juga ditemukan bahwa dari total responden yang diteliti hanya $10 \%$ UKM yang memiliki pegawai atau karyawan khsusus bertugas untuk menjalankan proses akuntansi usahanya sedangkan responden lainnya membuat laporan keuangannya sendiri dengan cara mendokumentasikan bukti-bukti transaksi usaha.

Tidak bisa dipungkiri, jika UKM memiliki karyawan khusus yang bertugas dalam bidang akuntansi, hal ini akan mendorong pelaku usaha untuk membuat pencatatan transaksi keuangan menjadi tertib dan disiplin, sehingga akan dapat mendukung penyajian laporan keuangan yang lebih baik dan berkualitas. Namun, jika pengusaha UKM hendak mempekerjakan staff khusus akuntansi, hal ini dianggap menjadi beban karena membutuhkan biaya yang lebih. Oleh karena itu, bagi sebagian UKM masih sulit untuk melakukan pencatatan akuntansi dan penyajian laporan keuangan yang berkualitas. Hal ini tidak jauh berbeda dengan hasil penelitian I Made Narsa (2012) yang menyatakan bahwa masih sedikit UKM yang memiliki pegawai khusus untuk dipekerjakan dibidang akuntansi dan pelaporan keuangan. Sehingga kualitas laporan keuangan usaha yang disajikan pun masih sangat sederhana.

\section{c. Standar Akuntansi dalam Membuat Laporan Keuangan}

Standar akuntansi keuangan merupakan standar yang menjadi acuan dan pedoman pelaku UKM dalam membuat laporan keuangan usahanya. Pada tabel 12 terlihat bahwa sebanyak $84 \%$ pengusaha UKM melakukan pencatatan atas transaksi keuangan usahanya, namun dari semua pengusaha UKM yang melakukan pencatatan transaksi keuangan atas usahanya tersebut sebanyak $90 \%$ tidak mengetahui standar akuntansi keuangan yang menjadi acuan dalam menyusun laporan keuangan usahanya. Jadi, mayoritas laporan keuangan yang disajikan tersebut hanya sebatas untuk mengetahui besaran laba dan perputaran arus kas usahanya saja. Sedangkan $10 \%$ menyatakan bahwa laporan keuangan yang disajikan tersebut 
sesuai dengan aturan perpajakan. Hal ini juga menunjukkan bahwa laporan keuangan tersebut banyak yang tidak sesuai dengan standar akuntansi keuangan.

Oleh karena itu, secara umum laporan keuangan yang disajikan tersebut kualitasnya masih tergolong rendah dan tidak sesuai dengan Standar Akuntansi Keuangan (SAK) maupun SAK ETAP sebagai acuan pembuatan laporan keuangan.

\section{d. Komponen Laporan Keuangan yang Disajikan}

Mayoritas pelaku usaha kecil menengah yang ada di kota Pekanbaru, sudah melakukan aktivitas pencatatan akuntansi atau pembukuan setiap transaksi usahanya. Hasil penelitian ini mengungkapkan bahwa $84 \%$ responden telah melakukan pencatatan transaksi keuangan (pembukuan transaksi) yaitu meliputi pendokumentasian bukti transaksi seperti bon, faktur, kwitansi dan juga telah melakukan pembukuan secara sederhana. Namun, dari $84 \%$ tersebut tidak semua Pelaku UKM tersebut mampu membuat laporan keuangan usahanya. Alasan responden tersebut tidak membuat laporan keuanganya karena pelaku usaha tersebut tidak mempunyai pengetahuan yang cukup mengenai cara membuat laporan keuangan.

Selain itu, UKM yang sudah membuat laporan keuangan usahanya, kualitas laporan keuangan yang dihasilkan tersebut masih tergolong kategori sangat rendah, sebab belum mampu menyajikan kondisi perusahaan secara nyata karena komponen laporan keuangan yang paling banyak disajikan adalah laporan rugi laba dan laporan posisi keuangan (Neraca). Tentu hal ini akan berdampak pada kualitas laporan keuangan yang akan disajikannya. Kemudian tidak sedikit juga laporan keuangan yang disajikan masih sebatas seadanya dan sangat sederhana. Adapun komponen laporan keuangan yang paling sering disajikan adalah laporan laba-rugi usaha dan laporan posisi keuangan (Neraca). Untuk lebih jelasnya mengenai komponen laporan keuangan yang disajikan UKM disajikan pada tabel 13.

Tabel 13. Komponen Laporan Keuangan yang disajikan UKM

\begin{tabular}{|c|c|c|}
\hline $\begin{array}{c}\text { Komponen } \\
\text { Laporan Keuangan }\end{array}$ & $\begin{array}{l}\text { Frek. } \\
\text { (unit) }\end{array}$ & $\%$ \\
\hline$A+B+C+D+E$ & 1 & 1 \\
\hline$A+B+C+E$ & 6 & 6 \\
\hline$A+C+D+E$ & 1 & 1 \\
\hline$B+C+D+E$ & 1 & 1 \\
\hline$A+C$ & 3 & 3 \\
\hline $\mathrm{B}+\mathrm{C}$ & 32 & 32 \\
\hline $\mathrm{B}+\mathrm{D}$ & 1 & 1 \\
\hline $\mathrm{C}+\mathrm{D}$ & 6 & 6 \\
\hline $\mathrm{B}$ & 1 & 1 \\
\hline $\mathrm{C}$ & 29 & 29 \\
\hline 0 & 19 & 19 \\
\hline Jumlah & 100 & 100 \\
\hline
\end{tabular}

Sumber: Data Olahan (2014)

Keterangan:

$\mathrm{A}=$ Laporan perubahan Modal

$\mathrm{B}=$ Laporan Posisi Keuangan (Neraca)

$\mathrm{C}=$ Laporan Rugi Laba

D = Laporan Arus Kas

$\mathrm{E}=$ Lainnya (keterangan mengenai laporan keuangan yang disajikan)

$0=$ Tidak menyajikan komponen laporan keuangan usaha

Berdasarkan tabel 13 dapat diketahui bahwa hanya $19 \%$ responden yang tidak melakukan penyajian laporan keuangan akuntansi sama sekali. Sedangkan UKM yang sudah menyediakan laporan keuangan secara lengkap hanya $1 \%$ responden yaitu terdiri atas laporan labarugi, laporan arus kas, laporan posisi keuangan dan laporan perubahan modal. Selain itu, komponen laporan keuangan yang paling dominan dibuat UKM yaitu sebanyak $32 \%$, adalah membuat laporan keuangan yang terdiri dari laporan labarugi dan laporan posisi keuangan. Oleh karena itu, secara umum dikatakan bahwa kualitas laporan keuangan yang disajikan UKM masih rendah. 
Pelaksanaan pembukuan akuntansi untuk menyediakan laporan keuangan yang informatif memang masih sulit bagi sebagian besar pelaku UKM. Hal ini disebabkan masih minimnya pengetahuan dan keterbatasan pemahaman akuntansi, rumitnya proses akuntansi dan tidak ada latar belakang pendidikan mengenai pencatatan akuntansi oleh pelaku UKM. Selain itu, pelaku usaha yang tidak membuat pencatatan akuntansi mengaku bahwa akuntansi itu rumit dan sulit. Apabila menyediakan karyawan khusus untuk melakukan pencatatan akuntansi akan menambah biaya tambahan, sehingga mengakibatkan pengusaha UKM kurang mampu menyajikan laporan keuangan usahanya. Hal ini juga diperkuat dengan anggapan pelaku UKM bahwa pencatatan akuntansi dan pembuatan laporan keuangan itu tidak begitu penting dan tidak berpengaruh pada aktivitas usaha yang dijalankannya.

Sejauh ini, laporan keuangan usaha yang telah dibuat, kebanyakan disajikan apabila ada pihak tertentu yang meminta laporan keuangan usahanya, misalnya salah satu syarat dari pihak perbankan jika ingin mengajukan pinjaman dan dari pihak perpajakan untuk penetapan besaran penghasilan kena pajak atas penghasilan usahanya.

Melihat pentingnya peranan laporan keuangan pada masa sekarang ini, sudah sewajarnya pengusaha UKM membuat laporan keuangan yang baik dan sesuai dengan standar akuntansi. Para pelaku UKM yang sudah membuat laporan keuangan menyatakan bahwa laporan keuangan tersebut sangat membantu mereka untuk mengetahui aktivitas bisinisnya selama ini. Berdasarkan pencatatan keuangan yang dibuatnya, pengusaha dapat membuat strategi pengembangan atau ekspansi usaha yang tepat. Salah satu responden juga mengaku melalui laporan keuangan yang dibuatnya, pihaknya lebih mudah untuk mengajukan pinjaman ke bank, karena pihak perbankan akan mengetahui kondisi UKM tersebut melalui laporan keuangan tersebut.

Selain itu, pelaku usaha itu juga mengaku sangat terbantu saat berhadapan dengan pihak finance/leasing ketika ingin membeli kendaraan usaha, yaitu seperti mobil pick-up sebagai salah satu kendaraan usaha untuk pengangkutan dalam memperlancar kegiatan usaha dan distribusi barang. Pihak kreditor meminta laporan keuangan usaha satu tahun terakhir, termasuk fotocopy tagihan rekening listrik dan tagihan telepon sebagai salah satu bentuk pengeluaran rutin. Dengan laporan keuangan tersebut pihak kreditor akan lebih yakin dan percaya terhadap pengusaha yang mengajukan kredit.

\section{PENUTUP}

1. Kualitas laporan keuangan UKM yang di Kota Pekanbaru masih tergolong sangat rendah. Masih banyak pelaku UKM yang belum membuat laporan keuangan usahanya. Terdapat $16 \%$ responden yang sama sekali tidak melakukan pembukuan dan pencatatan akuntansi. Sebanyak 90\% pengusaha UKM tidak mengetahui mengenai standar akuntansi dalam melakukan pencatatan akuntansi. Kemudian, hanya $10 \%$ UKM yang memiliki pegawai khusus mengerjakan transaksi keuangan dan laporan keuangan. Hal ini menunjukkan Kualitas laporan keuangannya yang disajikan masih sangat jauh dari standar akuntansi keuangan yang berlaku yaitu laporan keuangan yang disajikan hanya sebatas pembukuan biasa untuk mengetahui alur perputaran kas dan besarnya rugi atau laba yang diperoleh dalam waktu tertentu. Hal ini disebabkan rendahnya pengetahuan para pengusaha UKM mengenai akuntansi dan pelaporan keuangan usaha.

2. Terdapat beberapa kendala dalam melakukan pencatatan transaksi bagi pengusaha UKM, antara lain: (1) sulit untuk memisahkan antara transaksi pribadi dengan transaksi perusahaan, 
(2) kurang rajin dalam melakukan pencatatan harian, (3) kesibukan dan terlalu lelah untuk melakukan pencatatan, (4) tidak adanya pemahaman dan pengetahuan tentang akuntansi.

3. Guna meningkatkan kualitas laporan keuangan UKM di kota Pekanbaru, perlu diadakan sosialisasi mengenai informasi SAK-ETAP dan pelatihanpelatihan manajemen keuangan yang baik dan salah satunya pelatihan pembuatan laporan keuangan yang sesuai dengan SAK-ETAP sebagai standar akuntansi keuangan UKM.

Sosialisasi dan pelatihan akuntansi tersebut perlu dilaksanakan secara berkala dan berkelanjutan agar pemahaman pengusaha berkembang dan bertumbuh sehingga pengusaha UKM dapat meningkatkan pengetahuan dan pemahaman tentang perlunya pencatatan akuntansi dan penyajian laporan keuangan yang berkualitas.

\section{DAFTAR PUSTAKA}

Bestari Dwi Handayani. 2011. Faktor yang Mempengaruhi Penggunaan Informasi Akuntansi Usaha Kecil dan Menengah. Akuntabilitas. Sept 2011, Vol.11, No.1, ISSN 1412 0240.

Dita Purnama sari, 2013. Analisis FactorFaktor Yang Mempengaruhi Penyediaan dan Pengunaan Informasi Akuntansi Pada Usaha Kecil Dan Menengah Di Kecamatan Rumbai Pesisir. Pekanbaru: Universitas Riau.

I Made Narsa dan Agus Widodo, 2012. Mengungkap Kesiapan UMKM Dalam Implementasi Standar Akuntansi Keuangan Tanpa Akuntabilitas Public (PSAK ETAP) Untuk Meningkatkan Akses Modal Perbankan. Majalah Ekonomi. Tahun XXII, No. 3 Desember 2012.

Muhamad Wahyudi. 2009. Analisis FaktorFaktor yang Mempengaruhi Penggunaan Informasi Akuntansi pada Usaha Kecil dan Menengah (UKM) di Yogyakarta. Semarang: Program Pasca Sarjana UNDIP Semarang.

Rudianto. 2009. Pengantar akuntansi. Jakarta : Erlangga

Urata Shujiro, 2000, Policy
Recommendation for SME
Promotion in the Republic of
Indonesia. Tokyo : JICA.

